http:/www.journals.zu.edu.eg/journalDisplay.aspx?Journalld=1\&queryType=Master

\title{
EFFECT OF SPRAYING EXTRACTS OF ROCKET AND FENUGREEK SEED SPROUTS ON YIELD AND QUALITY OF FLAME SEEDLESS GRAPEVINES
}

\author{
Asmaa A. Ebrahim* \\ Viticulture Res. Dept. Hort. Res. Instit. ARC, Giza, Egypt \\ Received: 05/06/2017; Accepted: 16/07/2017
}

\begin{abstract}
This study was carried out during 2015 and 2016 seasons at Samalout district, Minia Governorate to study the effect of spraying extracts of rocket and fenugreek seed sprouts each at 0.5 to $2 \%$ on growth aspects, vine nutritional status, berry setting (\%), yield, berries colouration (\%) and berries quality of Flame seedless grapevines. Treating the vines three times with rocket or fenugreek seed sprouts extracts each at 0.5 to $2 \%$ resulted in an obvious promotion on all growth aspects, leaf pigments and nutrients, berry setting (\%), yield, berries colouration (\%) and berries quality relative to the control treatment. The promotion was related to the increase in the concentration of rocket and fenugreek seed sprouts extracts. The investigated parameters were unaffected with increasing concentration from 1.0 to $2.0(\%)$ from each material. Fenugreek seed sprouts was superior than using rocket seed sprout in this respect. Carrying out four sprays of extract of fenugreek seed sprouts at $1.0 \%$ was responsible for improving yield and berries quality of Flame seedless grapevines.
\end{abstract}

Key words: Extracts of rocket and fenugreek seed sprouts; berries colouration (\%), yield, berries quality, Flame seedless grapevines.

\section{INTRODUCTION}

Flame seedless grapevines cv grown under middle Egypt conditions suffers from irregular berries colouration which reflected in collapsing marketing of the fruit to local and foreign markets. Promoting berries colouration by using different chemicals causes the accumulation of harmful residual substances in the berries and reduces exportation process. It is necessary for avoiding the use of chemicals by application of extracts of crop seed sprouts which are promising in the long run of grapevines. Sprouting or germination of crop seeds may change the chemical composition of organic foods and enhance the biosynthesis of essential amino acids like glutamic acid, tryptophan and arginine, vitamins $\mathrm{B}$ and $\mathrm{C}$ and all essential macro and micronutrients and makes them high and very available to the plants (Cazoula et al., 2004; Cairney, 2005; Blommerson, 2007). Crop seed sprouts are responsible for supplying the

* Corresponding author: Tel. : +201001932127

E-mail address: faissalfadel@yahoo.com plants with their requirements from most organic foods like carbohydrates, proteins, fats, amino acids, vitamins, antioxidants and nutrients (Camacho et al., 1992; Cairney, 1995; Abdallah et al., 2000; Crews and Peoples, 2004).

Treating different species of fruit crops and other horticultural plants with crop seed sprouts extracts was accompanied with improving growth, plant nutritional status, fruit setting (\%), yield and fruit quality (Abdallah, 2008; Darwish, 2009; Anderson and Cedergreen, 2010; Al-Shereif et al., 2013; El-Sayed, 2014; El-Khawaga and Mansour, 2014; Ahmed and Habasy, 2014; Mohamed, 2014; Refaai, 2014a and b; Abd El-Rahman, 2015).

The objective of this study was to evaluate the effect of application of spraying two crop seed sprout extracts namely fenugreek and rocket seed sprouts on growth, yield and berries quality of Flame seedless grapevines. 


\section{MATERIALS AND METHODS}

This study was carried out during two successive seasons of 2015 and 2016 on fortyfour-year-old uniform in vigour Flame seedless grapevines grown on own roots in a private vineyard located at Samalout district, Minia Governorate, Egypt where the soil texture is clay and well drained and water table is not less than two meters deep. Vines are spaced at 2 meters between vine $\times 3$ meters between rows (700 vines per faddan). The selected vines (42 vines) were chosen as uniform in vigour as possible and devoted to achieve this study. The chosen vines were pruned during the first week of January in both seasons. Spur pruning system using cordon trellis supporting system was followed. Vine bud load for all the selected vines was adjusted to 72 eyes (on the basis of 20 fruiting spurs $x$ three eyes plus six replacement spurs $\mathrm{x}$ two eyes). Surface irrigation system was followed using Nile water (EC was $150 \mathrm{ppm}$ ).

This study contained seven treatments the following spraying were applied on the vine:

1. Control treatment (sprayed with water only).

2. Extract of rocket seed sprout at $0.5 \%$.

3. Extract of rocket seed sprout at $1.0 \%$.

4. Extract of rocket seed sprout at $2.0 \%$.

5. Extract of fenugreek seed sprout at $0.5 \%$.

6. Extract of fenugreek seed sprout at $1.0 \%$.

\section{Extract of fenugreek seed sprout at $2.0 \%$.}

Each treatment was replicated three times, two vines/each. Rocket seeds were sown at a rate of $30 \mathrm{~g}$ seeds $/ \mathrm{m}^{2}$, then they harvested at fully expanded green cotyledonny leaves stage (after eleven days from sowing). Fenugreek seeds were sown in dark place using glass jar method (Abdallah, 2008), then sprouts were harvested after three days from seed soaking. Sprouts of rocket and fenugreek were kept under $4^{\circ} \mathrm{C}$ in refrigerator till use. For application, sprouts of rocket and fenugreek seeds were homogenized with distilled water according to concentrations using an electric blender for five minutes, then filterated. The two crop seed sprouts were sprayed four times and two week intervals during both seasons at growth start $\left(1^{\text {st }}\right.$ of Mar.), $3^{\text {rd }}$ week of March, $1^{\text {st }}$ week of April and $3^{\text {rd }}$ week of April. Triton B as a wetting agent was added at $0.05 \%$. The foliar spray was done till runoff. Randomized complete block design (RCBD) was followed.

During both seasons, the following measurements were recorded:

1. Vegetative growth characteristics namely main shoot length $(\mathrm{cm})$, number of leaves/ shoot, leaf area $(\mathrm{cm})^{2}$ according to (Ahmed and Morsy, 1999), wood ripening coefficient (Bouard, 1966), cane thickness $(\mathrm{cm})$ and pruning wood weight/ vine $(\mathrm{kg})$.

2. Chlorophylls $\mathrm{a}$ and $\mathrm{b}$ and total carotenoids (mg/ g FW) according to Hiscox and Isralstam (1979).

3. Percentages of $\mathrm{N}, \mathrm{P}, \mathrm{K}$ and $\mathrm{Mg}$ in the petioles (on dry weight basis) according to (Summer, 1985; Wilde et al. 1985).

4. Percentage of berry setting, yield expressed in weight (kg.) and number of clusters per vine.

5. Weight (g.) and dimensions (length and width, in $\mathrm{cm}$ ) of cluster.

\section{Percentages of berries colouration.}

7. Physical and chemical characteristics of the berries namely weight (g.) and dimensions (longitudinal and equatorial $\mathrm{cm}$ ), TSS, total sugars (Lane and Eynon, 1966), total acidity (\%, as g tartaric acid/100 ml juice) according to $(A O A C, 2000)$ and total anthocyanins in the berries (mg/100g F.W) according to (Fulcki and Francis, 1968).

Statistical analysis was done and treatment means were compared using new LSD at $5 \%$ (according to Mead et al., 1993 ; Rao, 2007).

\section{RESULTS}

\section{Vegetative Growth Parameters}

It is clear from results in Table 3 that the tested treatments increased significantly growth parameters namely main shoot length, number of leaves/shoot, leaf area, wood ripening coefficient, cane thickness and pruning wood weight in the two seasons compared to the control treatment. The promotion was related to the increase in concentrations of both materials. Significant differences on these growth parameters were observed among most concentrations except among the higher two 
Table 1. Analysis of the tested soil

\begin{tabular}{lc}
\hline Constituent & Value \\
\hline Particle size & 7.1 \\
Sand (\%) & 20.0 \\
Silt (\%) & 72.9 \\
Clay (\%) & Clay \\
Texture & 7.95 \\
pH (1:2.5 extract) & 0.96 \\
EC (1 :2.5 extract) $\left(\mathbf{d s m}^{-1}\right) \mathbf{1 ~ c m / 2 5}^{\mathbf{0}} \mathbf{C}$. & 2.92 \\
OM (\%) & 1.91 \\
CaCO $\mathbf{3} \%)$ & 0.15 \\
Total N (\%) & 4.9 \\
Available P (Olsen, $\mathbf{p p m})$ & 500 \\
Available K (ammonium acetate, $\mathbf{p p m})$ & \\
\hline
\end{tabular}

Table 2. Chemical analyses for fenugreek and rocket seed sprouts

\begin{tabular}{lclc}
\hline \multicolumn{1}{c}{ Fenugreek (mg/100g FW) } & & Rocket (mg/100g FW) \\
\hline Constituent & Value & Constituent & Value \\
Asparatic acid & 2.2 & Cystine & 4.1 \\
Arginine & 2.1 & Cysteine & 3.9 \\
Alanine & 2.9 & Methionene & 3.8 \\
Isoleucin & 2.1 & Glutamic acid & 3.5 \\
Cystine & 1.9 & Thiamine & 0.16 \\
Cysteine & 1.8 & Riboflavin & 0.15 \\
Glutamic acid & 2.0 & Vitamin E & 0.94 \\
Methionene & 6.0 & Vitamin A & 4.4 \\
Lysine & 5.1 & Vitamin C & 101 \\
Vitamin A & 1.0 & K & 496 \\
Vitamin B1 & 0.32 & $\mathbf{P}$ & 1410 \\
Vitamin B2 & 0.30 & Mg & 460 \\
Vitamin B6 & 1.00 & Fe & 267 \\
Vitamin C & 2.00 & Mn & 16 \\
Ca & 220 & Zn & 255 \\
P & 341 & & \\
K & 469 & & \\
Mg & 371 & & \\
Fe & 242 & & \\
Phytic acid & 0.9 & & \\
Niacin & 1.4 & & \\
\hline
\end{tabular}


Table 3. Effect of rocket and fenugreek seed sprout extracts foliar spray on some vegetative growth parameters of Flame seedless grapevines during 2015 and 2016 seasons

\begin{tabular}{|c|c|c|c|c|c|c|c|c|c|c|c|c|}
\hline \multirow[t]{2}{*}{ Treatment } & \multicolumn{2}{|c|}{$\begin{array}{c}\text { Main shoot } \\
\text { length } \\
\text { (cm) }\end{array}$} & \multicolumn{2}{|c|}{$\begin{array}{c}\text { No. of } \\
\text { leaves/ } \\
\text { shoot }\end{array}$} & \multicolumn{2}{|c|}{$\begin{array}{l}\text { Leaf } \\
\text { area } \\
\left(\mathrm{cm}^{2}\right) \\
\end{array}$} & \multicolumn{2}{|c|}{$\begin{array}{c}\text { Wood } \\
\text { ripening } \\
\text { coefficient }\end{array}$} & \multicolumn{2}{|c|}{$\begin{array}{c}\text { Cane } \\
\text { thickness } \\
(\mathrm{cm}) \\
\end{array}$} & \multicolumn{2}{|c|}{$\begin{array}{c}\text { Pruning } \\
\text { wood weight } \\
(\mathrm{kg} .) / \mathrm{vine}\end{array}$} \\
\hline & 2015 & 2016 & 2015 & 2016 & 2015 & 2016 & 2015 & 2016 & 2015 & 2016 & 2015 & 2016 \\
\hline Control (sprayed with water) & 97.5 & 101.0 & 14.0 & 13.0 & 101.0 & 101.9 & 0.69 & 0.68 & 1.09 & 1.10 & 1.29 & 1.24 \\
\hline Rocket sprout extract at $0.5 \%$ & 101.0 & 104.6 & 16.0 & 15.0 & 103.6 & 105.0 & 0.75 & 0.76 & 1.16 & 1.16 & 1.35 & 1.36 \\
\hline Rocket sprout extract at $1.0 \%$ & 105.0 & 110.0 & 18.0 & 18.0 & 105.5 & 107.9 & 0.80 & 0.81 & 1.23 & 1.24 & 1.41 & 1.42 \\
\hline Rocket sprout at $2.0 \%$ & 105.6 & 110.6 & 18.0 & 18.0 & 106.0 & 108.0 & 0.81 & 0.82 & 1.24 & 1.25 & 1.42 & 1.43 \\
\hline Fenugreek seed sprout extract at $0.5 \%$ & 109.9 & 116.6 & 20.0 & 20.0 & 110.0 & 112.0 & 0.85 & 0.90 & 1.31 & 1.33 & 1.50 & 1.49 \\
\hline Fenugreek seed sprout extract at $1.0 \%$ & 114.9 & 121.6 & 22.0 & 22.0 & 112.9 & 114.0 & 0.90 & 0.91 & 1.37 & 1.40 & 1.56 & 1.54 \\
\hline Fenugreek seed sprout extract at $2.0 \%$ & 115.1 & 122.0 & 22.0 & 23.0 & 113.0 & 114.4 & 0.91 & 0.92 & 1.38 & 1.41 & 1.57 & 1.55 \\
\hline New LSD at $5 \%$ & 1.4 & 1.3 & 2.0 & 2.0 & 1.1 & 1.3 & 0.04 & 0.05 & 0.05 & 0.06 & 0.05 & 0.04 \\
\hline
\end{tabular}

concentrations namely 1.0 and $2.0 \%$. Using fenugreek seed sprout extract was significantly superior than using rocket seed sprout. The maximum values of these growth measurements were recorded on the vines that treated four times with extract of fenugreek seed sprout at $2.0 \%$. Untreating the vines with any crop seed sprout extract gave the minimum values. These results were true during both seasons.

\section{Leaf Chemical Components}

As shown in Table 4, chlorophylls a and b, total carotenoids, $\mathrm{N}, \mathrm{P}, \mathrm{K}$ and $\mathrm{Mg}$ in the leaves were significantly enhanced in response to treating the vines with any of the two crop seed sprouts at 0.5 to $2.0 \%$ compared to the control treatment. There was a gradual promotion on these chemical components with increasing concentrations of fenugreek and rocket seed sprout extracts from 0.5 to $2.0 \%$. Treating the vines with extract of fenugreek seed sprout was significantly superior than using rocket seed sprout in the two seasons. Increasing concentration of both crop seed sprout extracts from 1.0 to $2.0 \%$ had no significant promotion among them on these chemical constituents. The maximum values were recorded on the vines that treated four times with fenugreek seed sprout extract at $2.0 \%$ in both seasons. The untreated vines produced the lowest values. Similar trend was noticed during both seasons.

\section{Percentage of Berry Setting, Yield and Cluster Aspects}

Results in Table 5 clearly show that subjecting the vines to extracts of fenugreek or rocket seed sprout each at 0.5 to $2.0 \%$ significantly was responsible for improving percentage of berry setting, yield expressed in weight and number of clusters/vine as well as weight and dimensions of cluster relative to the check treatment. The promotion was in proportional to the increase in concentrations of both materials. Using extract of fenugreek seed sprout was significantly preferable than using extract of rocket seed sprout in improving berry setting, yield and cluster aspects. No significant promotion was detected on these parameters among the higher two concentrations namely $(1.0$ and $2.0 \%)$, therefore, the recommended concentration from economical point of view was $1 \%$. From economical point of view, using fenugreek seed sprout extract at $1 \%$ gave the best results with regard to yield. Under such promised treatment, yield per vine reached 10.0 and $14.0 \mathrm{~kg}$ compared with the yield of untreated vines that reached 8.2 and $8.4 \mathrm{~kg}$ during both seasons, 
Table 4. Effect of rocket and fenugreek seed sprout extracts foliar spray on some leaf chemical components of Flame seedless grapevines during 2015 and 2016 seasons

\begin{tabular}{|c|c|c|c|c|c|c|c|c|c|c|c|c|c|c|}
\hline \multirow[t]{2}{*}{$\overline{\text { Treatment }}$} & \multicolumn{4}{|c|}{$\begin{array}{c}\text { Chlorophyll Chlorophyll } \\
\text { a (mg/g b (mg/g }\end{array}$} & \multicolumn{2}{|c|}{$\begin{array}{c}\text { Total } \\
\text { carotenoids } \\
(\mathrm{mg} / \mathrm{g} \mathrm{FW})\end{array}$} & \multicolumn{2}{|c|}{$\begin{array}{c}\text { Leaf } N \\
(\%)\end{array}$} & \multicolumn{2}{|c|}{$\begin{array}{c}\text { Leaf P } \\
(\%)\end{array}$} & \multicolumn{2}{|c|}{$\begin{array}{c}\text { Leaf K } \\
(\%)\end{array}$} & \multicolumn{2}{|c|}{$\begin{array}{c}\text { Leaf Mg } \\
(\%)\end{array}$} \\
\hline & 2015 & 2016 & 2015 & 2016 & 2015 & 2016 & 2015 & 2016 & 2015 & 2016 & 2015 & 2016 & 2015 & 2016 \\
\hline Control (sprayed with water) & 3.9 & 4.0 & 1.1 & 1.0 & 0.9 & 1.1 & 1.57 & 1.61 & 0.13 & 0.14 & 1.11 & 1.14 & 0.56 & 0.59 \\
\hline Rocket sprout extract at $0.5 \%$ & 4.6 & 4.5 & 1.4 & 1.4 & 1.2 & 1.3 & 1.63 & 1.67 & 0.17 & 0.17 & 1.17 & 1.49 & 0.60 & 0.63 \\
\hline Rocket sprout extract at $1.0 \%$ & 5.1 & 5.0 & 1.7 & 1.8 & 1.6 & 1.5 & 1.70 & 1.72 & 0.20 & 0.20 & 1.23 & 1.25 & 0.65 & 0.66 \\
\hline Rocket sprout at $2.0 \%$ & 5.2 & 5.1 & 1.8 & 1.9 & 1.7 & 1.6 & 1.71 & 1.73 & 0.21 & 0.21 & 1.24 & 1.26 & 0.66 & 0.67 \\
\hline Fenugreek seed sprout extract at $0.5 \%$ & 5.6 & 5.7 & 2.4 & 2.5 & 2.1 & 1.9 & 1.77 & 1.81 & 0.25 & 0.24 & 1.30 & 1.31 & 0.71 & 0.70 \\
\hline Fenugreek seed sprout extract at $1.0 \%$ & 6.1 & 6.3 & 2.7 & 3.0 & 2.4 & 2.2 & 1.83 & 1.90 & 0.29 & 0.27 & 1.35 & 1.36 & 0.75 & 0.73 \\
\hline Fenugreek seed sprout extract at $2.0 \%$ & 6.2 & 6.4 & 2.8 & 3.1 & 2.5 & 2.3 & 1.84 & 1.91 & 0.30 & 0.28 & 1.36 & 1.37 & 0.76 & 0.74 \\
\hline New LSD at 5\% & 0.4 & 0.5 & 0.2 & 0.3 & 0.2 & 0.2 & 0.04 & 0.05 & 0.04 & 0.03 & 0.04 & 0.04 & 0.03 & 0.02 \\
\hline
\end{tabular}

Table 5. Effect of rocket and fenugreek seed sprout extracts foliar spray on the percentage of berry setting, yield, cluster weight and dimensions (length and width) and berries colouration of Flame seedless grapevines during 2015 and 2016 seasons

\begin{tabular}{|c|c|c|c|c|c|c|c|c|c|c|c|}
\hline \multirow[t]{2}{*}{ Treatment } & \multicolumn{2}{|c|}{$\begin{array}{c}\text { Berry } \\
\text { setting } \\
(\%)\end{array}$} & \multicolumn{2}{|c|}{$\begin{array}{l}\text { No. of } \\
\text { clusters/ } \\
\text { vine }\end{array}$} & \multicolumn{2}{|c|}{$\begin{array}{l}\text { Yield/ } \\
\text { vine } \\
\text { (kg.) }\end{array}$} & $\begin{array}{c}\text { Cluster } \\
\text { weight } \\
\text { (g) }\end{array}$ & $\begin{array}{c}\text { Cluster } \\
\text { length } \\
\text { (cm) }\end{array}$ & $\begin{array}{c}\text { Cluster } \\
\text { width } \\
\text { (cm) }\end{array}$ & \multicolumn{2}{|c|}{$\begin{array}{c}\text { Berries } \\
\text { colouration } \\
(\%)\end{array}$} \\
\hline & 2015 & 2016 & 2015 & 2016 & 2015 & 2016 & 20152016 & 20152016 & 520 & 2015 & 2016 \\
\hline Control (sprayed with water) & 13.0 & 12.9 & 24.0 & 24.0 & 8.2 & 8.4 & 341351 & 15.115 .8 & 10.110 .5 & 59.90 & 60.10 \\
\hline Rocket sprout extract at $0.5 \%$ & 14.6 & 15.0 & 25.0 & 26.0 & 8.9 & 9.5 & 357367 & 15.716 .5 & 10.711 .1 & 61.91 & 64.11 \\
\hline Rocket sprout extract at $1.0 \%$ & 16.0 & 16.9 & 25.0 & 29.0 & 9.3 & 11.0 & 371381 & 16.317 .5 & 11.512 .1 & 64.91 & 66.99 \\
\hline Rocket sprout at $2.0 \%$ & 16.1 & 17.0 & 25.0 & 30.0 & 9.3 & 11.5 & $373 \quad 382$ & 16.417 .6 & 11.612 .2 & 65.00 & 67.11 \\
\hline Fenugreek seed sprout extract at $0.5 \%$ & 17.4 & 18.1 & 25.0 & 32.0 & 9.7 & 12.7 & 386397 & 17.118 .2 & 12.513 .4 & 71.91 & 73.11 \\
\hline Fenugreek seed sprout extract at $1.0 \%$ & 18.5 & 19.5 & 25.0 & 34.0 & 10.0 & 14.0 & 401411 & 18.419 .0 & 13.414 .4 & 77.92 & 80.00 \\
\hline Fenugreek seed sprout extract at $2.0 \%$ & 18.6 & 19.6 & 25.0 & 34.0 & 10.1 & 14.0 & 402412 & 18.519 .1 & 13.514 .5 & 78.11 & 80.60 \\
\hline New LSD at $5 \%$ & 0.9 & 1.0 & NS & 2.0 & 0.3 & 0.6 & $11 \quad 11$ & $0.5 \quad 0.6$ & $0.5 \quad 0.4$ & 1.12 & 1.13 \\
\hline
\end{tabular}


respectively. The percentage of increment due to using the suggested treatment over the control treatment reached 22.0 and $66.7 \%$ during both seasons, respectively. The present treatments had no significant effect on the number of clusters in the first season only.

\section{Percentage of Berries Colouration}

As shown in Table 5, percentage of berries colouration was significantly enhanced in response to treating the vines with extracts of fenugreek or rocket seed sprouts each at 0.5 to $2 \%$ relative to the check treatment. The promotion was associated with increasing concentrations of each material. Using fenugreek seed sprout extract significantly was accompanied with enhancing berries colouration (\%) compared to the use of rocket seed sprout extract in both seasons. The best results were observed on the vines that treated four times with fenugreek seed sprout extract at $2.0 \%$. Under such promised treatment, values of berries colouration during both seasons were 78.11 and $80.60 \%$, respectively. The lowest values of berries colouration (\%) (69.6 and $60.10 \%$ ) were recorded on untreated vines. These results were true during both seasons.

\section{Physical and Chemical Characteristics of the Berries}

It can be stated from the results in Table 6 that treating Flame seedless grapevines four times with fenugreek or rocket seed sprouts each at 0.5 to $2.0 \%$, significantly was accompanied with improving berries quality in terms of increasing berry weight and dimensions (longitudinal and equatorial), TSS (\%), total sugars (\%) and total anthocyanins and decreasing total acidity (\%) compared to the control treatment. The promotion was related to the increase in concentrations of both materials. Using fenugreek seed sprout extract was significantly preferable than using rocket seed sprout extract in improving quality of the berries in the two seasons. Increasing concentrations from 1.0 to $2.0 \%$ failed to show significant promotion on quality parameters. Therefore, the best results with regard to berries quality from economical point of view were obtained on the vines that treated with fenugreek seed sprout extract at $1.0 \%$. Unfavourable effects on berries quality were observed on the untreated vines. Similar results were announced during both seasons.

Table 6. Effect of rocket and fenugreek seed sprout extracts foliar sprays on some physical and chemical characteristics of the berries of Superior grapevines during 2015 and 2016 seasons

\begin{tabular}{|c|c|c|c|c|c|c|c|c|c|c|c|c|c|c|}
\hline \multirow[t]{2}{*}{ Treatment } & \multicolumn{2}{|c|}{$\begin{array}{c}\text { Berry } \\
\text { weight } \\
\text { (g) }\end{array}$} & \multicolumn{2}{|c|}{$\begin{array}{c}\text { Berry } \\
\text { longitudinal } \\
\text { (cm) }\end{array}$} & \multicolumn{2}{|c|}{$\begin{array}{c}\text { Berry } \\
\text { equatorial } \\
\text { (cm) }\end{array}$} & \multicolumn{2}{|c|}{$\begin{array}{l}\text { TSS } \\
(\%)\end{array}$} & \multicolumn{2}{|c|}{$\begin{array}{c}\text { Total } \\
\text { sugars } \\
(\%)\end{array}$} & \multicolumn{2}{|c|}{$\begin{array}{c}\text { Total } \\
\text { acidity } \\
(\%)\end{array}$} & \multicolumn{2}{|c|}{$\begin{array}{c}\text { Total } \\
\text { anothocynans } \\
(\mathrm{mg} / 100 \mathrm{~g})\end{array}$} \\
\hline & 2015 & 2016 & 2015 & 2016 & 2015 & 2016 & 2015 & 2016 & 2015 & 2016 & 2015 & 2016 & 2015 & 2016 \\
\hline$\overline{\text { Control (sprayed with water) }}$ & 4.11 & 4.20 & 1.59 & 1.61 & 1.22 & 1.23 & 17.7 & $\overline{18.0}$ & 14.9 & 15.0 & 0.70 & 0.718 & 21.9 & 22.3 \\
\hline Rocket sprout extract at $0.5 \%$ & 4.41 & 4.50 & 1.64 & 1.66 & 1.28 & 1.29 & 18.1 & 18.4 & 15.3 & 15.4 & 0.68 & 0.691 & 24.1 & 25.0 \\
\hline Rocket sprout extract at $1.0 \%$ & 4.77 & 4.86 & 1.69 & 1.72 & 1.33 & 1.35 & 18.6 & 18.8 & 15.5 & 15.8 & 0.661 & 0.671 & 28.8 & 29.1 \\
\hline Rocket sprout at $2.0 \%$ & 4.80 & 4.89 & 1.70 & 1.73 & 1.34 & 1.36 & 18.7 & 18.9 & 15.6 & 15.9 & 0.659 & 0.669 & 28.3 & 29.2 \\
\hline Fenugreek seed sprout extract at $0.5 \%$ & 5.00 & 5.09 & 1.77 & 1.79 & 1.40 & 1.41 & 19.1 & 19.4 & 16.0 & 16.4 & 0.630 & 0.640 & 31.3 & 32.0 \\
\hline Fenugreek seed sprout extract at $1.0 \%$ & 5.31 & 5.40 & 1.86 & 1.85 & 1.45 & 1.47 & 19.6 & 19.8 & 16.4 & 16.8 & 0.610 & 0.618 & 35.0 & 35.8 \\
\hline Fenugreek seed sprout extract at $2.0 \%$ & 5.32 & 5.41 & 1.87 & 1.86 & 1.46 & 1.48 & 19.7 & 19.9 & 16.5 & 16.9 & 0.608 & 0.617 & 35.3 & 36.0 \\
\hline New LSD at $5 \%$ & 0.10 & 0.08 & 0.04 & 0.04 & 0.05 & 0.05 & 0.3 & 0.3 & 0.2 & 0.3 & 0.018 & 0.019 & 2.1 & 1.9 \\
\hline
\end{tabular}




\section{DISCUSSION}

The outstanding effect of fenugreek and rocket seed sprouts on fruiting of Flame seedless grapevines might be attributed to their higher content of amino acids, vitamins and nutrients (Camacho et al., 1992; Cairney, 1995; Abdallah et al., 2000; Cazoula et al., 2004; Crews and Peoples, 2004; Cairney, 2005; Blommerson, 2007; Abdallah, 2008). The obtained results are in agreement with those of Darwish (2009), Anderson and Cedergreen (2010), Al- Shereif et al. (2013), El-Sayed (2014), El- Khawaga and Mansour (2014), Ahmed and Habasy (2014), Mohamed (2014), Refaai (2014a) and (2014b) and Abd El-Rahman (2015).

\section{Conclusion}

The investigated parameters were unaffected with increasing the concentration from 1.0 to $2.0 \%$ from each material. Fenugreek seed sprouts was superior than using rocket seed sprout in this respect. Carrying out four sprays of extract of fenugreek seed sprouts at $1.0 \%$ was responsible for improving yield and berries quality of Flame seedless grapevines.

\section{REFERENCES}

Abd El-Rahman, M.M.A. (2015). Yield and fruit quality of washington navel oranges as influenced by foliar application of fenugreek and rocket seed sprouts. World Rural Observations, 7 (2): 99-104.

Abdallah, M.M.F. (2008). Seed sprouts approach heritage to improve food quality. Arab J. Agric. Sci., 1 (92): 469-475.

Abdallah, M.M.F., A.A.G. Abdallah, I.I. ElAish and M.F. El-Shereif (2000). Production of tomato and cucumber transplants in greenhouse using local bagusse and haysinth composts as a substitute for peatmoss. J. Agric. Mansoura Univ., 25(9): 5851-5866.

Ahmed, F.F. and M.H. Morsy (1999). A new method for measuring leaf area in different fruit species. Minia J., Agric. Res. and Dev., 19: 97-105.

Ahmed, F.F. and R.E.Y. Habasy (2014). Productive performance of Washington Navel orange trees in relative to foliar application of barley seed sprout and royal jelly. World Rural Observations, 6 (4): 169114.

Al-Shereif, E., A.K. Hagazy, N.H. Gomaa and M.O. Hassan (2013). Allelaphathic effect of black mustard and root extudates on some crops and weeds. Plant Daninha Viscoa- MG, 31 (1): $1-9$.

Anderson, M. and N. Cedergreen (2010). Plant growth is stimulated by tea seed extract a new natural growth regulator. Hort. Sci., 48 (12): 1848- 1853.

AOAC (2000). Official Methods of Analysis. Benjamin Franklin Station, Washington, DC, SA, 490-510.

Blommerson, A. (2007). Cruciferous sprout complex. Monograph. 227 Bellevue Way NE 83.

Bouard, J. (1966). Recharches, physiologiques sur la vigen at en particulier sur laoudment des serments. Thesis Sci. Nat. Bardeux France, 34 .

Cairney, E. (1995). Sprouters Handbook Argyll publishing Glen drangelSargyl PA 223 AE Scotland, 20- 25.

Cairney, E. (2005). The Sprouters Handbook Argyll publishing Glen drangelSargyl PA 223 A22 3 AE Scotland, 41-45.

Camacho, LC., C. Slerra, R. Compos, E. Guzman and Marchus (1992). Nutritional changes caused by the germination of legumes commonly eaten in China. Arch Latinoan Ch. Nut., 42: 283-290.

Cazoula, I., V. Marsili and G.L.K. Gionferanceshi (2004). Synthesis of antioxidants in wheat sprouts. J. Agric. Chen., 52: 5201- 5206.

Crews, T.E. and M.B. Peoples (2004). Legume versus fertilizer sources of nitrogen, ecological trade effects and human needs. Agric. Cosytermus and Environ., 102 (3): 279-297.

Darwish, S.N.A.S. (2009). Production of some vegetable crop transplants organically under protected cultivation. M. Sc. Thesis Fac. Agric. Ain Shams Univ., Egypt. 
El-Khawaga, A.S. and A.E.M. Mansour (2014). Promoting productivity of Washington Navel orange trees by using some crop seeds sprout extracts, silicon and glutathione Middle East J. Appl. Sci., 4 (3): 779-785.

El-Sayed, F.I.I. (2014). Effect of seed sprout extract of some crop species on organically produced vegetables M. Sc. Thesis Fac. Agric. Ain Shams Univ., Egypt.

Fulcki, T. and F.J. Francis (1968). Quantitative methods for anthocyanins II Determination of total anthocyanins and degradative index for berry juice J. Food Sci., 33: 78-83.

Hiscox, A. and B. Isralstam (1979). Method for the extraction of chlorophyll from leaf tissue without maceration. Can. J. Bot., 57: 13321334.

Lane, J.H. and L. Eynon (1965). Determination of reducing sugars by means of fehling solution with methylene blue as indicator. ACAC Washington DC, USA, 490-510.

Mead, R., R.N. Currnow and A.M. Harted (1993). Statistical Methods in Agricultural and Experimental Biology. $2^{\text {nd }}$ Ed. Chapman and Hall, London, 10-44.
Mohamed, A.Y.A. (2014). Effect of spraying Fenugreek seed sprout and some nutrients on fruiting of Keitte mango trees grown under Aswan region conditions World Rural Observations, 6 (4): 103-108.

Rao, G.N. (2007). Statistics for Agricultural Sciences. BS Publications.

Refaai, M.M. (2014a). Impact of spraying extracts of fenugreek and rocket seed sprouts on fruiting of Keitte mango trees. World Rural Observations, 6 (4): 75-80.

Refaai, M.M. (2014b): Response of Zaghloul date palms grown under Minia region conditions to spraying wheat seed sprout extract and nano- boron. Stem Cell., 5 (4): 22-28.

Summer, M.F. (1985). Diagnosis and Recommendation Integrated system (DRIS) as a guide to orchard fertilization. Hort. Abst., 55 (8):7502.

Wilde, S.A., R.B. Corey, J.G. Layer and G.K. Voigt (1985). Soil and Plant Analysis for Tree Culture. Oxford and IBH publishing Co., New Delhi, India, 1- 70.

\section{تأثير الرش بمستخلصات نبت بذور الجرجير والحلبة على كمية وجودة المحصول فى كرمات العنب الفليم سبدلس أسماء أنور إبراهيم$$
\text { قسم بحوث العنب ـ معهد بحوث البساتين - مركز البحوث الزر اعية ـ الجيزة ـ مصر }
$$

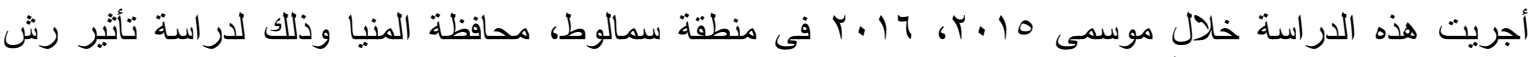

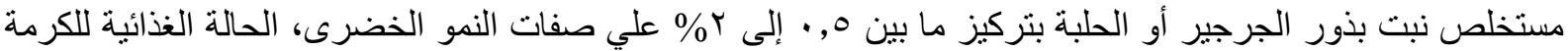

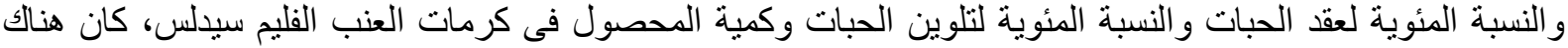

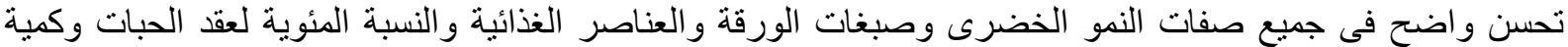

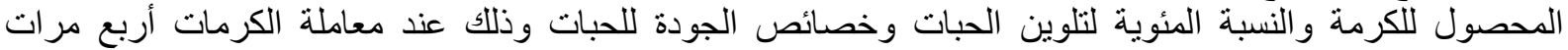

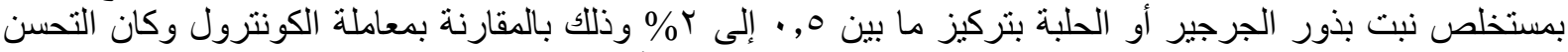

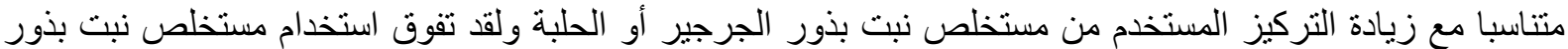
الحلبة عن مستخلص نبادة نبت بذور الجرجير فى هذا الصدد، لأجل تحسين كمية المحصول وجئ الحودة الحبات فئ كرمات العنب

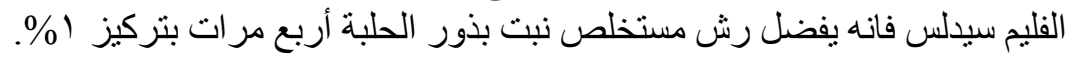

